\title{
CARDIAC OUTPUT IN POSTURAL HYPOTENSION ${ }^{1}$
}

\author{
By J. B. HICKAM AND W. W. PRYOR 2 \\ (From the Department of Medicine, Duke University School of Medicine, Durham, \\ North Carolina)
}

(Submitted for publication May 23, 1949; accepted, February 12, 1951)

The arterial pressure is kept at a nearly constant level in normal man by simultaneous adjustments of the cardiac output and calibre of the arterioles. The normal response on motionless standing is arteriolar constriction and a moderate fall in cardiac output. The arteriolar constriction is usually sufficient to prevent a fall in mean pressure. In certain persons a marked fall in arterial pressure occurs on motionless standing. The purpose of this study is to evaluate the relative importance of an abnormal decline in cardiac output and of a failure of normal vasoconstriction in producing the fall in arterial pressure.

\section{METHODS}

Among the 12 patients studied, postural hypotension was idiopathic in three, associated with diabetes mellitus in five, with tabes dorsalis in two, with probable syringomyelia in one, and followed bilateral sympathectomy $\left(T_{1}\right.$ through $\mathrm{L}_{1}$ ) for hypertension in one case. ${ }^{3}$ All subjects were studied in the morning, usually after a light breakfast. Observations were made on a tilting table in the supine position, and at a foot-down angle which was usually $60^{\circ}$ from the horizontal. In the latter position the patient was supported by a foot-plate. The tilted position was maintained for three to four minutes before beginning air collection for determination of oxygen consumption. The air collection usually occupied two minutes, and toward the end of this time blood samples were drawn and pressure measurements were begun. The total duration of tilt was seven to eight minutes. The time allowed for adjustment to the tilted position is therefore quite short. However, if more time is allowed to reach a steady state during the tilt, there is danger of collapse. None of these subjects showed evidence of impending collapse. In one subject (J. D.) A-V blood oxygen differences were determined three minutes apart during the tilt, and in two subjects (C. G. and J. P.) duplicate venous samples were taken approximately one minute apart

1 This work was supported by a grant from the Life Insurance Medical Research Fund and the Anna $H$. Hanes Memorial Fund.

2 U. S. Public Health Service Postdoctorate Research Fellow.

3 This patient was studied through the courtesy of Dr. Keith Grimson, Department of Surgery, Duke University School of Medicine. (before and after drawing the arterial sample). The results, presented in Table $I$, do not indicate rapid shifts in $\mathrm{A}-\mathrm{V}$ oxygen difference during the period of measurement.

Albumin infusion consisted of $75 \mathrm{gm}$. of human serum albumin ${ }^{4}$ made up with normal saline to a volume of 1,300 cc. and given intravenously within a period of 15 minutes.

Cardiac outputs were determined by the Fick principle following intracardiac catheterization (1). Mixed venous blood was obtained from the atrium or the pulmonary artery; arterial blood, from the brachial artery through an inlying needle. Blood oxygen contents were determined by a spectrophotometric method (2) or by the method of Van Slyke and Plazin (3). In the latter case, duplicate analyses were required to check within 0.1 vol. \%. With the spectrophotometric method, duplicate determinations are not in general done because of the simplicity of the technique. Repeated determinations of arterio-venous oxygen difference on the same blood samples yield results within 0.2 vol. $\%$, unless the hemolyzed samples are grossly turbid. All samples are checked for turbidity before reading. Spectrophotometric oxygen determinations were made in subjects J. D., C. G., C. C., J. P., and C. B. Oxygen consumption was measured by timed collection of expired air in Douglas bags, analysis in the Haldane apparatus, and volume measurements in a Tissot spirometer. Intracardiac and arterial pressures were measured by Hamilton manometers. The point of zero reference was $5 \mathrm{~cm}$. below the fourth costochondral junction in the supine position and in the two instances where measurements were made at $-30^{\circ}$ (head down). In the upright tilts the zero point was taken at the fourth costochondral junction. Mean arterial pressures were obtained by planimetry.

"Calculated resistance" is expressed as the ratio between mean arterial pressure in $\mathrm{mm}$. $\mathrm{Hg}$ and cardiac index in liters per minute per square meter of body surface. This is a general form for the expression of resistance (4). In the present study it is intended to serve as a rough index of over-all changes in the arteriolar system of a given subject. A rise in the function is taken to indicate over-all narrowing of the arteriolar bed, while a fall indicates dilatation. For this purpose it must be admitted that the function is quite imperfect. In the study of regional vascular changes, the general expression for resistance has been refined by corrections for yield pressure and viscosity (5). It is uncertain how much gain in reliability would be achieved by the application of these corrections in the present study. A major uncer-

\footnotetext{
4 Supplied by the American Red Cross.
} 
tainty arises because comparisons are made of resistances in different body positions. The change from supine to tilted position causes a change in distribution of blood flow to the body, with a resultant change in the contribution of different vascular regions to the total resistance. Since resistance is affected by local factors such as length of small vessels and tissue pressure, and since the influence of these factors is altered by a change in distribution of flow, even the refined formula may not well reflect arteriolar changes in this particular situation. For this reason the general expression is used. Its limitations are emphasized by terming it "calculated resistance." The function is studied only as it changes with body position in a given individual. Direct comparisons of calculated resistance are not made between different subjects, nor are resistances compared in the same subject before and after the administration of albumin.

\section{RESULTS}

The data are presented in Table $I^{5}$ The last two cases in the table, G. G. and T. I., usually had

5 Observations on J. A. were made by Drs. Ebert and Borden of Minneapolis, Minnesota, who kindly made the data available for presentation in this paper.

TABLE I

\begin{tabular}{|c|c|c|c|c|c|c|c|c|c|c|c|c|c|c|c|c|}
\hline \multirow[b]{2}{*}{ Subject } & \multirow[b]{2}{*}{ Comment } & \multirow[b]{2}{*}{ Position } & \multirow[b]{2}{*}{ 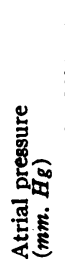 } & \multicolumn{3}{|c|}{$\begin{array}{c}\text { Arterial } \\
\text { pressure } \\
\left(\mathbf{m} m . \boldsymbol{H}_{\mathbf{g}}\right)\end{array}$} & \multirow{2}{*}{ 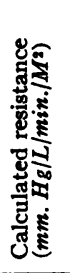 } & \multicolumn{3}{|c|}{$\begin{array}{l}\text { Blood oxygen } \\
\text { content } \\
\text { (vol. \%) }\end{array}$} & \multirow{2}{*}{ 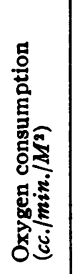 } & \multirow[b]{2}{*}{ 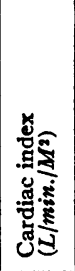 } & \multirow[b]{2}{*}{ 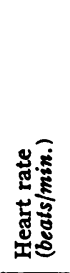 } & \multicolumn{3}{|c|}{$\begin{array}{l}\text { Per cent of } \\
\text { resting } \\
\text { value }\end{array}$} \\
\hline & & & & 总 & 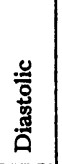 & ¿্ّ & & 蛋 & 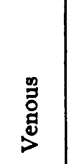 & 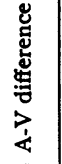 & & & & 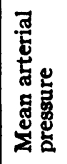 & 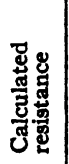 & 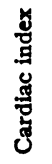 \\
\hline J. D. & $\begin{array}{c}\text { Female, } 65, \text { Idiopathic } \\
\text { postural hypotension }\end{array}$ & $\begin{array}{l}\text { Flat } \\
50^{\circ}, 2 \mathrm{~min} . \\
50^{\circ}, 5 \mathrm{~min} . \\
-30^{\circ}\end{array}$ & $\begin{array}{r}1 \\
-5 \\
4\end{array}$ & $\begin{array}{r}164 \\
56 \\
129\end{array}$ & $\begin{array}{l}79 \\
33 \\
65\end{array}$ & $\begin{array}{r}119 \\
43 \\
96\end{array}$ & $\begin{array}{l}44 \\
17 \\
26\end{array}$ & \begin{tabular}{|l|}
10.4 \\
11.2 \\
11.7 \\
12.0
\end{tabular} & $\begin{array}{l}6.1 \\
4.9 \\
6.1 \\
8.7\end{array}$ & $\begin{array}{l}4.3 \\
6.3 \\
5.6 \\
3.3\end{array}$ & $\begin{array}{l}116 \\
139 \\
121\end{array}$ & $\begin{array}{l}2.7 \\
2.5 \\
3.7\end{array}$ & $\begin{array}{l}91 \\
99 \\
93\end{array}$ & $\begin{array}{l}36 \\
81\end{array}$ & $\begin{array}{l}39 \\
59\end{array}$ & $\begin{array}{r}93 \\
137\end{array}$ \\
\hline C. G. & $\begin{array}{l}\text { Male, 22, } \\
\text { postural hypotes, }\end{array}$ & $\begin{array}{r}\text { Flat } \\
60^{\circ} \\
-30^{\circ}\end{array}$ & $\begin{array}{r}0 \\
-4 \\
1\end{array}$ & $\begin{array}{r}133 \\
86 \\
139 \\
\end{array}$ & $\begin{array}{l}86 \\
51 \\
88\end{array}$ & \begin{tabular}{r|}
107 \\
64 \\
110
\end{tabular} & $\begin{array}{l}22 \\
19 \\
22\end{array}$ & $\begin{array}{l}14.5 \\
14.0 \\
13.8 \\
\end{array}$ & $\begin{array}{c}12.0 \\
12.1 * \\
9.5 \\
9.6 * \\
10.8\end{array}$ & $\begin{array}{l}2.5 \\
4.5 \\
3.0\end{array}$ & $\begin{array}{l}119 \\
149 \\
148\end{array}$ & $\begin{array}{l}4.8 \\
3.3 \\
4.9\end{array}$ & $\begin{array}{l}104 \\
140 \\
110\end{array}$ & $\begin{array}{r}60 \\
103\end{array}$ & $\begin{array}{r}86 \\
100\end{array}$ & $\begin{array}{r}69 \\
102\end{array}$ \\
\hline c. C. & $\begin{array}{l}\text { Male, } 60 \text {. Diabetes, } \\
\text { postural hypotension }\end{array}$ & $\begin{array}{l}\text { Flat } \\
60^{\circ}\end{array}$ & $\begin{array}{l}-4 \\
-6\end{array}$ & 191 & $\begin{array}{l}94 \\
82 \\
\end{array}$ & $\begin{array}{r}130 \\
96 \\
\end{array}$ & $\begin{array}{l}32 \\
36 \\
\end{array}$ & $\begin{array}{l}19.1 \\
17.8\end{array}$ & $\begin{array}{l}14.4 \\
11.0\end{array}$ & $\begin{array}{l}4.7 \\
6.8 \\
\end{array}$ & $\begin{array}{l}193 \\
186 \\
\end{array}$ & $\begin{array}{l}4.1 \\
2.7\end{array}$ & $\begin{array}{l}113 \\
126\end{array}$ & 74 & 112 & 66 \\
\hline J. P. & $\begin{array}{l}\text { Male, 43, PSyringomyelia, } \\
\text { postural hypotension }\end{array}$ & $\begin{array}{l}\text { Flat } \\
60^{\circ}\end{array}$ & $\begin{array}{r}5 \\
-3\end{array}$ & $\begin{array}{r}115 \\
73 \\
\end{array}$ & $\begin{array}{l}72 \\
55 \\
\end{array}$ & $\begin{array}{l}90 \\
60 \\
\end{array}$ & $\begin{array}{l}45 \\
35\end{array}$ & $\begin{array}{l}19.1 \\
19.6 \\
\end{array}$ & \begin{tabular}{|l|}
12.1 \\
11.6 \\
$11.2 *$ \\
\end{tabular} & $\begin{array}{l}7.0 \\
8.2 \\
\end{array}$ & 138 & $\begin{array}{l}2.0 \\
1.7 \dagger \\
\end{array}$ & $\begin{array}{r}57 \\
101 \\
\end{array}$ & 67 & 78 & 85 \\
\hline C. $\mathrm{B}$. & $\begin{array}{l}\text { Male, 46, Diabetes, } \\
\text { postural hypotension }\end{array}$ & Flat & $\begin{array}{l}\mathbf{0} \\
\mathbf{0}\end{array}$ & $\begin{array}{l}147 \\
120\end{array}$ & $\begin{array}{l}80 \\
76 \\
\end{array}$ & $\begin{array}{r}111 \\
92\end{array}$ & $\begin{array}{l}33 \\
30\end{array}$ & $\begin{array}{l}15.1 \\
15.1 \\
\end{array}$ & $\begin{array}{r}10.3 \\
9.8\end{array}$ & $\begin{array}{l}4.8 \\
5.3 \\
\end{array}$ & $\begin{array}{l}163 \\
162\end{array}$ & $\begin{array}{l}3.4 \\
3.1\end{array}$ & $\begin{array}{r}77 \\
103\end{array}$ & 83 & 91 & 91 \\
\hline R.S. & $\begin{array}{l}\text { Male, 25, Hypertension, } \\
\text { four years post- } \\
\text { 8ympathectomy }\end{array}$ & $\begin{array}{l}\text { Flat } \\
60^{\circ}\end{array}$ & & $\begin{array}{l}141 \\
114\end{array}$ & $\begin{array}{l}82 \\
71\end{array}$ & $\begin{array}{r}107 \\
82\end{array}$ & $\begin{array}{l}30 \\
33\end{array}$ & $\begin{array}{l}19.3 \\
19.5\end{array}$ & $\begin{array}{l}15.1 \\
13.8\end{array}$ & $\begin{array}{l}4.2 \\
5.7\end{array}$ & $\begin{array}{l}151 \\
141\end{array}$ & $\begin{array}{l}3.6 \\
2.5\end{array}$ & $\begin{array}{l}47 \\
75\end{array}$ & 77 & 110 & 70 \\
\hline J. A. & $\begin{array}{l}\text { Male, 49, Idiopathic } \\
\text { postural hypotension }\end{array}$ & Flat & & & & $\begin{array}{l}77 \\
63\end{array}$ & $\begin{array}{l}17 \\
30\end{array}$ & \begin{tabular}{|l|}
19.3 \\
19.6
\end{tabular} & $\begin{array}{l}16.4 \\
13.1\end{array}$ & $\begin{array}{l}2.9 \\
6.5\end{array}$ & $\begin{array}{l}137 \\
138\end{array}$ & $\begin{array}{l}4.6 \\
2.1\end{array}$ & & 82 & 176 & 46 \\
\hline C. H. & $\begin{array}{l}\text { Male, 62, Idiopathic } \\
\text { postural hypotension } \\
\text { Five days later } \\
\text { After } 75 \text { gm. albumin in } \\
1,300 \mathrm{cc} \text {. saline }\end{array}$ & $\begin{array}{l}\text { Flat } \\
60^{\circ} \\
60^{\circ} \\
60^{\circ}\end{array}$ & $\begin{array}{r}0 \\
-5 \\
-5\end{array}$ & $\begin{array}{r}168 \\
85 \\
68 \\
143\end{array}$ & $\begin{array}{l}83 \\
56 \\
45 \\
79\end{array}$ & $\begin{array}{r}117 \\
66 \\
53 \\
108\end{array}$ & $\begin{array}{l}33 \\
37 \\
37 \\
45\end{array}$ & $\begin{array}{l}16.8 \\
17.7 \\
15.4 \\
13.0\end{array}$ & $\begin{array}{r}12.5 \\
9.0 \\
6.2 \\
7.7\end{array}$ & $\begin{array}{l}4.3 \\
8.6 \\
9.2 \\
5.3\end{array}$ & $\begin{array}{l}151 \\
154 \\
133 \\
127\end{array}$ & $\begin{array}{l}3.5 \\
1.8 \\
1.4 \\
2.4\end{array}$ & $\begin{array}{l}71 \\
94 \\
94 \\
69\end{array}$ & $\begin{array}{l}56 \\
45\end{array}$ & $\begin{array}{l}112 \\
112\end{array}$ & $\begin{array}{l}51 \\
40\end{array}$ \\
\hline A. B. & $\begin{array}{l}\text { Male, 37, Diabetes, } \\
\text { postural hypotension } \\
\text { After } 75 \text { gm. albumin in } \\
1,300 \mathrm{cc} \text {. saline }\end{array}$ & $\begin{array}{l}\text { Flat } \\
60^{\circ} \\
\text { Flat } \\
60^{\circ}\end{array}$ & & $\begin{array}{r}132 \\
72 \\
167 \\
140 \\
\end{array}$ & $\begin{array}{l}85 \\
46 \\
94 \\
92 \\
\end{array}$ & $\begin{array}{l}103 \\
57 \\
123 \\
108 \\
\end{array}$ & $\begin{array}{l}37 \\
38 \\
23 \\
43\end{array}$ & \begin{tabular}{|l|}
19.7 \\
19.9 \\
15.3 \\
15.9 \\
\end{tabular} & $\begin{array}{r}14.6 \\
9.7 \\
12.7 \\
10.5 \\
\end{array}$ & \begin{tabular}{r|r|}
5.1 & 1 \\
10.2 & 2.6 \\
5.4 & \\
\end{tabular} & $\begin{array}{l}142 \\
149 \\
140 \\
137 \\
\end{array}$ & $\begin{array}{l}2.8 \\
1.5 \\
5.4 \\
2.5\end{array}$ & $\begin{array}{r}91 \\
104 \\
99 \\
92 \\
\end{array}$ & $\begin{array}{l}55 \\
88\end{array}$ & $\begin{array}{l}103 \\
187\end{array}$ & $\begin{array}{l}54 \\
46\end{array}$ \\
\hline L. M. & $\begin{array}{l}\text { Female, } 36 \text {, Tabes, } \\
\text { postural hypotension } \\
\text { After } 75 \mathrm{gm} \text {. albumin in } \\
1,300 \mathrm{cc} \text {. saline }\end{array}$ & $\begin{array}{l}\text { Flat } \\
60^{\circ} \\
\text { Flat } \\
60^{\circ}\end{array}$ & $\begin{array}{l}+1 \\
+3 \\
+8 \\
0\end{array}$ & $\begin{array}{r}173 \\
74 \\
151 \\
189\end{array}$ & $\begin{array}{r}117 \\
45 \\
101 \\
127 \\
\end{array}$ & $\begin{array}{l}143 \\
57 \\
125 \\
154 \\
\end{array}$ & $\begin{array}{l}26 \\
22 \\
21 \\
33\end{array}$ & $\begin{array}{l}12.6 \\
13.2 \\
10.6 \\
11.2\end{array}$ & $\begin{array}{l}9.6 \\
6.9 \\
7.5 \\
7.5\end{array}$ & $\begin{array}{l}3.0 \\
6.3 \\
3.1 \\
3.7\end{array}$ & $\begin{array}{l}163 \\
167 \\
186 \\
173\end{array}$ & $\begin{array}{l}5.5 \\
2.6 \\
6.1 \\
4.7\end{array}$ & $\begin{array}{l}103 \\
118 \\
103 \\
144 \\
\end{array}$ & $\begin{array}{r}40 \\
123 \\
\end{array}$ & $\begin{array}{r}85 \\
157\end{array}$ & $\begin{array}{l}47 \\
77\end{array}$ \\
\hline G. G. & $\begin{array}{l}\text { Male, 30, Diabetes, irregu- } \\
\text { lar postural hypotension } \\
\text { After } 75 \text { gm. albumin in } \\
1,300 \text { cc. saline } \\
\text { Separate study }\end{array}$ & $\begin{array}{l}\text { Flat } \\
60^{\circ} \\
\text { Flat } \\
60^{\circ} \\
\text { Flat } \\
60^{\circ}\end{array}$ & $\begin{array}{r}-1 \\
-7 \\
+8 \\
-2 \\
0 \\
-1\end{array}$ & $\begin{array}{r}99 \\
85 \\
117 \\
108 \\
115 \\
107\end{array}$ & $\begin{array}{l}61 \\
60 \\
70 \\
64 \\
67 \\
78\end{array}$ & $\begin{array}{l}75 \\
68 \\
89 \\
80 \\
88 \\
88\end{array}$ & $\begin{array}{l}17 \\
34 \\
17 \\
24 \\
19 \\
42\end{array}$ & \begin{tabular}{|l|}
15.9 \\
16.9 \\
13.2 \\
12.9 \\
17.2 \\
17.9 \\
\end{tabular} & $\begin{array}{r}12.4 \\
7.8 \\
9.8 \\
7.7 \\
13.1 \\
9.9\end{array}$ & $\begin{array}{l}3.5 \\
9.1 \\
3.4 \\
5.2 \\
4.1 \\
8.0\end{array}$ & $\begin{array}{l}150 \\
177 \\
177 \dagger \\
179 \\
192 \\
169\end{array}$ & $\begin{array}{l}4.3 \\
2.0 \\
5.2 \\
3.4 \\
4.7 \\
2.1\end{array}$ & $\begin{array}{r}90 \\
123 \\
83 \\
94 \\
95 \\
125\end{array}$ & $\begin{array}{r}91 \\
91 \\
100 \\
\end{array}$ & $\begin{array}{l}200 \\
141 \\
220\end{array}$ & $\begin{array}{l}47 \\
65 \\
45\end{array}$ \\
\hline T. I. & $\begin{array}{l}\text { Male, 29, Tabes, irregular } \\
\text { postural hypotension } \\
\text { After } 75 \mathrm{gm} \text {. albumin in } \\
1,300 \mathrm{cc} \text {. saline }\end{array}$ & $\begin{array}{l}\text { Flat } \\
60^{\circ} \\
\text { Flat } \\
60^{\circ}\end{array}$ & $\begin{array}{l}+1 \\
+2 \\
+6 \\
+5\end{array}$ & $\begin{array}{l}121 \\
118 \\
155 \\
151\end{array}$ & $\begin{array}{l}72 \\
80 \\
87 \\
89\end{array}$ & $\begin{array}{r}92 \\
95 \\
114 \\
115\end{array}$ & $\begin{array}{l}30 \\
37 \\
37 \\
34\end{array}$ & \begin{tabular}{|l|}
18.7 \\
18.9 \\
14.6 \\
14.8
\end{tabular} & \begin{tabular}{|l|}
14.7 \\
14.1 \\
10.6 \\
11.4
\end{tabular} & $\begin{array}{l}4.0 \\
4.8 \\
4.0 \\
3.4\end{array}$ & $\begin{array}{l}123 \\
123 \dagger \\
125 \\
115\end{array}$ & $\begin{array}{l}3.1 \\
2.6 \\
3.1 \\
3.4\end{array}$ & $\begin{array}{l}103 \\
123 \\
114 \\
109\end{array}$ & $\begin{array}{l}103 \\
101\end{array}$ & $\begin{array}{r}123 \\
92\end{array}$ & $\begin{array}{r}84 \\
110\end{array}$ \\
\hline
\end{tabular}

* Samples collected approximately one minute apart.

† Calculation employs preceding oxygen consumption. 


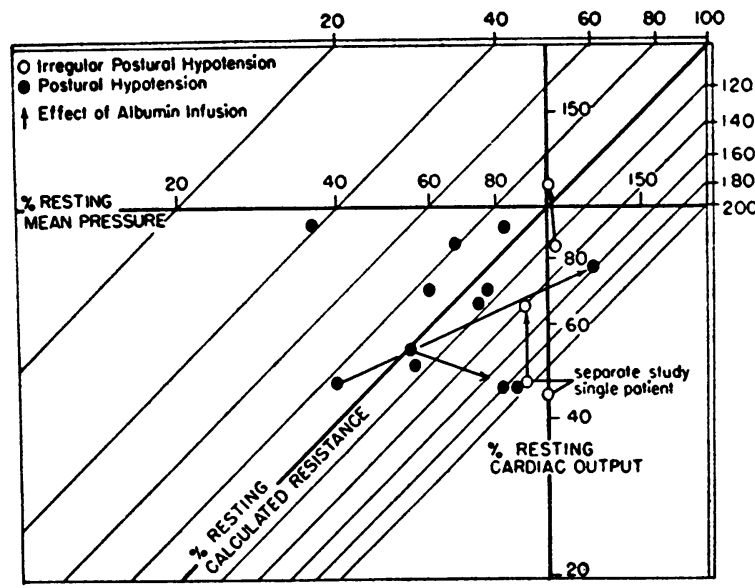

Fig. 1. Effect of Change from Supine to Upright Position on Cardiac Output, Mean Arterial PresSURe, and Calculated Resistance

The resting, supine state of each subject is represented by the origin. Each plotted point represents a determination in the tilted position. Changes in output, mean arterial pressure, and calculated resistance are expressed as percentage deviations from the resting levels, which are taken to be $100 \%$. Arrows connecting two points indicate that an albumin infusion has been given to a particular subject. The point toward which the arrow is directed represents the effect of tilt after infusion, as referred to measurements in the supine position, also after albumin.

severe weakness and giddiness in the upright position, often had marked postural hypotension, but showed little or none during the study. These patients had no varicosities or other known anatomical abnormalities interfering with venous return. They are classified as having "irregular postural hypotension."

An over-all view of the results is provided by Figure 1. In this figure the resting, supine state of each subject is represented by the origin. Changes in cardiac output, mean arterial pressure, and calculated resistance during tilt are expressed for each subject by the location of a point indicating percentage deviation from the resting levels, which are taken to be $100 \%$. Each plotted point represents a determination in the tilted position. Where two points are connected by an arrow, they both represent the same subject and indicate that an albumin infusion has been given. The point toward which the arrow is directed represents the condition during tilt after albumin has been given. These points, like the others, indicate percentage change from control measurements in the supine position. After the administration of albumin new control measurements were made in the supine position. The values obtained in the subsequent tilt were referred to these new control values.

In Figure 1, the average normal postural reaction would be represented by a region directly below the origin centering about the $75 \%$ level on the cardiac output axis. This corresponds to a maintenance of the resting mean arterial pressure, a fall of $25 \%$ in cardiac output, and an increase of about $33 \%$ in calculated resistance $(6,7)$.

The two subjects with "irregular postural hypotension" are represented in Figure 1 by open circles. One of these (T. I.) fell within the normal range, since he maintained his pressure and had only a small decline in output on tilt. The other (G. G.), who was studied twice, showed little or no pressure drop on tilt, but had a very large fall in cardiac output. Consequently, this subject had a great increase in calculated resistance during tilt. In terms of maintaining arterial pressure, both of these subjects at the time of study had an adequate vasoconstrictor response to a drop in cardiac output.

The other ten subjects are represented in the figure by solid circles. Eight of these showed little change in calculated resistance during tilt. In very broad terms, the greater the fall in cardiac output, the greater was the drop in arterial pressure, expressed as percentages. In three of these subjects (A. B., C. H., and L. M.) both cardiac output and arterial pressure fell below $60 \%$ of the resting levels.

The remaining two subjects show wide deviations from this broad picture. J. A. had a large drop in cardiac output but only an $18 \%$ decrease in pressure. There was a large rise in calculated resistance. His behavior is quite like that of G. G., who was classified as "irregular postural hypotension." The difference in classification, which is somewhat artificial, is based on the clear failure of the present subject to maintain his pressure on tilt at the time of study. The other subject, J. D., had the severest postural hypotension of the group. She often fainted in a chair. This patient had the greatest percentage fall in pressure on tilt, but there was little decline in output. There was a large decrease in calculated resistance. When this patient was tilted $30^{\circ}$ head down there was a moderate fall in pressure despite an increased cardiac 
output. Again, there was a sizable drop in calculated resistance. The other patient (C. G.) who was tilted head down showed no change in output, pressure, or resistance.

In four subjects (C. G., C. C., J. A., and G. G.) the resting cardiac index was between 4.0 and 5.0, and in one (L. M.) it was 5.5. The largest cardiac index falls of the group occurred in three of these subjects during tilt. This suggests that anxiety may have played a part in some of the postural reactions.

Albumin was given to five subjects. In all cases the absolute values of cardiac output and arterial pressure were distinctly higher in the tilted position after albumin than in the tilted position before albumin. In four cases (A. B., L. M., G. G., and T. I.) data are available to describe the changes on tilt after albumin in terms of percentage deviation from the resting level. The results are represented in Figure 1 by the points toward which arrows are directed. The two patients with "irregular" postural hypotension (G. G. and T. I.) continued to maintain their blood pressures during tilt as they had before albumin. As compared with the prealbumin state, the cardiac outputs were relatively higher and the increase in resistance relatively less. In the other two patients, who had wellmarked postural hypotension, the most striking change after albumin was the improvement in maintenance of arterial pressure during tilt. One subject showed a much smaller percentage fall in output than before; the other had a slightly greater percentage fall. Before albumin, neither subject had much change in calculated resistance during tilt. After albumin both cases showed a wellmarked increase in calculated resistance during tilt. The increase in calculated resistance was unexpected. It suggests an increase in arteriolar reactivity after albumin, but the expression for resistance is not sufficiently exact to make this secure.

\section{DISCUSSION}

In the over-all view, significant postural falls in blood pressure were more consistently associated with failure of normal arteriolar constriction (as indicated by lack of increase in calculated re-' sistance) than with abnormal decline in cardiac output. With a single exception, the subjects with significant postural hypotension showed on tilting a very minor increase in peripheral resistance or an actual fall. This is in general agreement with the findings of Stead and Ebert (8), who concluded on other grounds that failure of arteriolar constriction in response to a fall in blood pressure is fundamental to the production of postural hypotension. A similar conclusion was reached by Ellis and Haynes (9), who measured the cardiac output of two subjects by the acetylene method and found no more than a normal decrease in the tilted position.

One subject (J. D.), who had the most severe postural hypotension of the group, showed a considerable fall in calculated resistance on being tilted in either direction. The mechanism of this fall is not clear. It may result from passive dilatation of arterioles below heart level under increased hydrostatic pressure, thus providing a wide outflow bed. This possibility was suggested by Ellis and Haynes.

The postural fall in cardiac output was variable. From inspection of Figure 1 it is apparent that significant postural hypotension can occur without a greater than normal fall in cardiac output, and that a very large postural fall in cardiac output can occur without a significant drop in blood pressure. However, large pressure drops are often associated with large drops in output. The increase in actual output of tilted subjects after albumin suggests that these large output falls resulted from an inadequate venous return to the heart. The most apparent cause for inadequate return is abnormal dilatation of the venous system under pressure. Filling this system with a larger blood volume would improve venous return to the heart. Normally, the venous system resists passive dilatation under hydrostatic pressure in the upright position, and venous return is well maintained.

Active venous constriction is a familiar response to circulatory inadequacy, as in shock and congestive heart failure. It can occur rapidly in acute pericardial tamponade (10). It is quite possible that an increase in venous tone is an important, normal response to assuming the upright position. The present results suggest that such a response would assist in maintaining the cardiac output, just as arteriolar constriction maintains the blood pressure. 


\section{SUMMARY AND CONCLUSIONS}

1. Observations have been made on postural reactions of cardiac output and blood pressure in 12 subjects with postural hypotension.

2. Well-marked and even extreme postural hypotension can occur on the basis of failure of arteriolar constriction with no more than a normal postural decrease in cardiac output. Slight to moderate falls in mean arterial pressure have been observed in subjects with very large postural falls in cardiac output and large, though not completely compensatory, increases in calculated resistance. However, large postural falls in arterial pressure were often associated with large falls in cardiac output. In these cases the calculated resistance showed little change on tilt.

3. Large infusions of human serum albumin were given in five cases. In each case there was an increase in cardiac output in the tilted position as compared with the cardiac output in the tilted position before albumin infusion. Arterial pressure was well maintained during tilt. In two cases the response of calculated resistance to posture was greatly increased by the infusion. In two cases, the response was decreased.

4. The data suggest that postural hypotension is primarily dependent upon inadequate arteriolar tone in the upright position. The degree of postural hypotension is often intensified by a large postural fall in cardiac output. It is suggested that this may result from an associated deficiency in venous tone.

\section{REFERENCES}

1. Cournand, A., and Ranges, H. A., Catheterization of the right auricle in man. Proc. Soc. Exper. Biol. \& Med., 1941, 46, 462.

2. Hickam, J. B., and Frayser, R., Spectrophotometric determination of blood oxygen. J. Biol. Chem., 1949, 180, 457.

3. Peters, J. P., and Van Slyke, D. D., Quantitative Clinical Chemistry. Vol. II, Methods. Williams \& Wilkins Co., Baltimore, 1932, (1943 reprint).

4. Apéria, A., Hemodynamical studies. Skandinav. Arch. f. Physiol., 1940, Suppl. 16 (to Vol. 83).

5. Lamport, H., Improvements in calculation of renal resistance to blood flow. Charts for osmotic pressure and viscosity of blood. J. Clin. Invest., 1943, 22, 461.

6. McMichael, J., and Sharpey-Schafer, E. P., Cardiac output in man by a direct Fick method. Effects of posture, venous pressure change, atropine, and adrenaline. British Heart J., 1944, 6, 33.

7. Stead, E. A., Jr., Warren, J. V., Merrill, A. J., and Brannon, E. S., The cardiac output in male subjects as measured by the technique of right atrial catheterization. Normal values with observations on the effect of anxiety and tilting. J. Clin. Invest., 1945, 24, 326.

8. Stead, E. A., Jr., and Ebert, R. V., Postural hypotension; a disease of the sympathetic nervous system. Arch. Int. Med., 1941, 67, 546.

9. Ellis, L. B., and Haynes, F. W., Postural hypotension with particular reference to its occurrence in disease of the central nervous system. Arch. Int. Med., 1936, 58, 773.

10. Cooper, F. W., Jr., Stead, E. A., Jr., and Warren, J. $V$., The beneficial effect of intravenous infusions in acute pericardial tamponade. Ann. Surg., 1944, 120, 822. 